\title{
PHYSICAL ACTIVITY AND ENVIRONMENT: THE INFLUENCE OF URBAN GREEN SPACES ON HEALTH
}

\author{
ATIVIDADE FÍSICA EAMBIENTE: A INFLUÊNCIA DOS PARQUES VERDES URBANOS NA SAÚDE
}

ACTIVIDAD FISICA Y AMBIENTE: LA INFLUENCIA DE LOS PARQUES VERDES URBANOS EN LA SALUD

Original Article

ARTIGO ORIGINAL Artículo Original

\section{Juliana Felipe ${ }^{1}$}

(Physical Education Professional)

Marcus Vinicius Pimenta Rodrigues ${ }^{1}$ (Biomedical Scientist)

Aline Duarte Ferreira²

(Physiotherapist)

Elivelton Silva Fonseca'

(Geographer)

Gabrielle Gomes dos Santos

Ribeiro $^{3}$

(Statistician)

Alba Regina Azevedo Arana ${ }^{1}$

(Geographer)

1. Universidade do Oeste Paulista (UNOESTE), Graduate Program of Environmental and Regional Development Studies (PPGMADRE), Presidente Prudente, SP, Brazil. 2. Universidade do Oeste Paulista (UNOESTE), Department of Physiotherapy and Biomedicine, Presidente Prudente, SP, Brazil. 3. Universidade do Oeste Paulista (UNOESTE), CPA (Internal Evaluation Committee) Statistics Department, Presidente Prudente, SP, Brazil.

\section{Correspondence:}

Alba Regina Azevedo Arana Rod. Raposo Tavares, Km 572, Presidente Prudente, SP, Brazil. 19067-175. alba@unoeste.br

\begin{abstract}
Introduction: Urban green spaces can offer opportunities for regular physical activity, providing benefits in the lives of members of the population, such as physical, social and affective health. The aim of this article consists of analyzing the influence of urban green spaces on physical activity, focusing on urban environmental quality and the health of those who engage in physical activities in open areas. The study has a multidisciplinary approach from the perspective of environmental health. Method: The study design was based on qualitative research, using a bibliographic and document search as well as field surveys, whose technique involved direct observation (DO). The sample selection was based on Miot (2011), consisting of a total of 36 individuals aged between 18 and 40 years, who perform physical activities regularly, at least three times a week, for at least 50 minutes. Questionnaires were also applied using the IPAQ (assessment of physical activity) and Borg Scale parameters. Results: The study showed that the research participants became more active, possibly being stimulated and motivated by their surroundings with widespread vegetation cover, the good infrastructure of the venue and the guidance provided during the research. Conclusion: The research project showed that the greater the frequency and intensity of physical activity in open areas, the better the body's physiological adaptability. Level of Evidence Il; Prognostic study.
\end{abstract}

Keywords: Health; Environmental quality; Physical exercise.

\section{RESUMO}

Introdução: Os parques verdes urbanos podem oferecer oportunidades para a prática regular de atividade física, proporcionando benefícios para a vida da população, como por exemplo, saúde física, social e afetiva. O objetivo do presente artigo consiste em analisar a influência dos parques verdes urbanos na prática de atividades físicas, focando-se na qualidade ambiental urbana e na saúde dos praticantes de atividades físicas em áreas abertas. O estudo tem uma abordagem multidisciplinar segundo a perspectiva da saúde ambiental. Método: O projeto de estudo baseou-se em pesquisa qualitativa, utilizando pesquisa bibliográfica e documental e levantamentos de campo, cuja técnica contou com a observação direta (DO). A seleção da amostra foi baseada em Miot (2011), contando com36 indivíduos com idade entre 18 e 40 anos que praticam regularmente atividades fisicas, pelo menos, três vezes por semana, por no mínimo 50 minutos. Também foram realizados questionários utilizando o IPAC (nivel de atividade física avaliado) e os parâmetros da Escala de Borg. Resultados: O estudo mostrou que os participantes da pesquisa se tornaram mais ativos, possivelmente, sendo estimulados e motivados pelo ambiente com grande presença de vegetação, a boa infraestrutura do local e as orientações feitas durante a pesquisa. Conclusão: A pesquisa mostrou que quanto maior a frequência e a intensidade da atividade física em áreas abertas, melhoréa adaptabilidade fisiológica do organismo. Nível de evidência ll; Estudo prognóstico.

\section{Descritores: Saúde; Qualidade ambiental; Exercício físico.}

\section{RESUMEN}

Introducción: Los parques verdes urbanos pueden ofrecer oportunidades para la práctica regular de actividad física, proporcionando beneficios para la vida de la población, como por ejemplo, salud física, social y afectiva. El objetivo del presente artículo consiste en analizar la influencia de los parques verdes urbanos en la práctica de actividades físicas, enfocándose en la calidad ambiental urbana y la salud de los practicantes de actividades físicas en áreas abiertas. El estudio tiene un abordaje multidisciplinario según la perspectiva de la salud ambiental. Método: El proyecto de estudio se basó en la investigación cualitativa, mediante búsqueda bibliográfica y documental, y levantamientos de campo, cuya técnica contó con la observación directa (OD). La selección de la muestra se basó en Miot (2011), contando con 36 individuos con edad entre 18 y 40 años, que practican regularmente actividades físicas, al menos tres veces por semana, durante al menos 50 minutos. También fueron realizados cuestionarios utilizando el IPAC (nivel de actividad física evaluado) y los parámetros de la Escala de Borg. Resultados: El estudio mostró que los participantes de la investigación se volvieron más activos, posiblemente siendo estimulados y motivados por el ambiente con gran presencia de vegetación y la buen a infraestructura del local y las orientaciones realizadas durante la investigación. Conclusión: La investigación mostró que cuanto mayor es la frecuencia e intensidad de la actividad física en áreas abiertas, mejor es la adaptabilidad fisiológica del organismo. Nivel de evidencia ll; Estudio pronóstico.

Descriptores: Salud; Calidad ambiental; Ejercicio físico. 


\section{INTRODUCTION}

Currently, the population, including people from all social classes and age groups, is becoming increasingly aware that performing physical exercises is necessary not only to maintain a good shape but also to maintain good health.

The negative impact of sedentarism significantly outweighs eventual complications resulting from physical exercise, which has an interesting risk-benefit relationship. Thus, the environment where physical exercise is performed is extremely important.

Environments such as green areas combat air pollution through photosynthesis, regulate humidity and air temperature, and reduce noise levels, working as a buffer against city noise. ${ }^{2}$ This is a global interest issue that deserves attention from health professionals, environmentalists, and public managers as it involves public policies designed to promote health, prevent diseases, and provide better living conditions for individuals.

This study aimed to answer the following questions: What is the importance of urban parks and green areas in physical exercise practice? Do urban parks with green areas improve the population's quality of life and well-being? Thus, our hypothesis was that the regular performance of aerobic physical exercise in urban parks affects the respiratory quality of an individual, even in an open environment.

Individuals who regularly perform physical exercise respond better to pollution because they are better adapted physiologically.

This study has multidisciplinary implications and approaches, which complement each other within the scope of environmental health. Urban life is often seen as stressful, polluted, and filled with conflicts that can affect the quality of life. Thus, urban parks with green areas contribute to improvement in the quality of life as well as in the health and well-being.

The objective of this study was to address the influence of urban green parks on physical exercise practice and their importance in urban environmental quality and health of individuals who perform physical exercise in open areas.

\section{METHODOLOGY}

The study methods were based on qualitative research, and bibliographical survey research, documentary research, and intensive direct observation were used. The qualitative approach aims to relate theory and data and theory and action by understanding phenomena from descriptive and interpretative perspectives and applies the researcher's personal experiences. ${ }^{3}$

Bibliographical research included selected literature sources and field research on individuals who perform physical exercise at Parque do Povo (People's Park), located in the city of Presidente Prudente, São Paulo, Brazil. Field research was conducted in two phases: the first in February 2016 and the second in July 2016, between 5:00 and 7:00 PM.

Sample calculation was based on the study by Miot ${ }^{4}$ and included a total of 36 participants. Inclusion criteria were age between 18 and 40 years, exercise practice at least three times a week for at least 50 min at Parque do Povo, and no history of chronic lung disease and/or recent episodes of upper respiratory infections. The study was approved by the Research Ethics Committee (Comitê de Ética e Pesquisa) of Oeste Paulista University (CAAE 46057715.2.0000.5515), and all participants provided written informed consent.

This was a primary, uncontrolled longitudinal prospective study. Participants underwent an initial evaluation for data collection on personal characteristics, vital signs, preexisting morbidities, smoking history, and anthropometry.
Participants' physical activity levels were evaluated using the International Physical Activity Questionnaire (IPAQ) validated by Pardini et al. (2001). ${ }^{5}$ The IPAQ is an instrument that estimates the weekly time spent in performing physical activities of moderate-to-vigorous intensity and in different life contexts (physical exercise, work, household chores, transportation, and leisure). We evaluated physical activity levels by classifying the participants as follows:

1. Very active: participants who fulfilled the following exercise recommendations: a) vigorous, $\geq 5$ days/week, $\geq 30$ min per session or b) moderate, $\geq 3$ days/week, $\geq 20$ min per session + moderate and/or walking $\geq 5$ days/ week, $\geq 30$ min per session

2. Active: participants who fulfilled the following exercise recommendations: a) vigorous, $\geq 3$ days/week, $\geq 20$ min per session; b) moderate or walking, $\geq 5$ days/week, $\geq 30$ min per session; or (c) any added activity, $\geq 5$ days/week, $\geq 150 \mathrm{~min} /$ week (walking + moderate + vigorous)

3. Irregularly active: participants who fulfilled at least one of the recommended criteria for activity frequency or duration: a) frequency, 5 days/ week or b) duration, $150 \mathrm{~min} /$ week.

After this initial evaluation period, participants were invited to walk in moderate intensity for $30 \mathrm{~min}$ on a $2-\mathrm{km}$ pre-established route at Parque do Povo (Figure 1).

The exercise was supervised, and physical effort perception was measured using the Borg scale. After walking, all participants were re-evaluated, and vital signs were measured immediately after the exercise and after a 15-min rest.

Statistical data were analyzed using the Action Stat software, a user-friendly statistical system using R language and integrated with the Excel software. Initially, data were descriptively analyzed by calculating measurements, such as mean and standard deviation, and creating tables and graphs. Then, the dataset was divided into first and second phases and male and female groups. These groups were compared for some dataset variables.

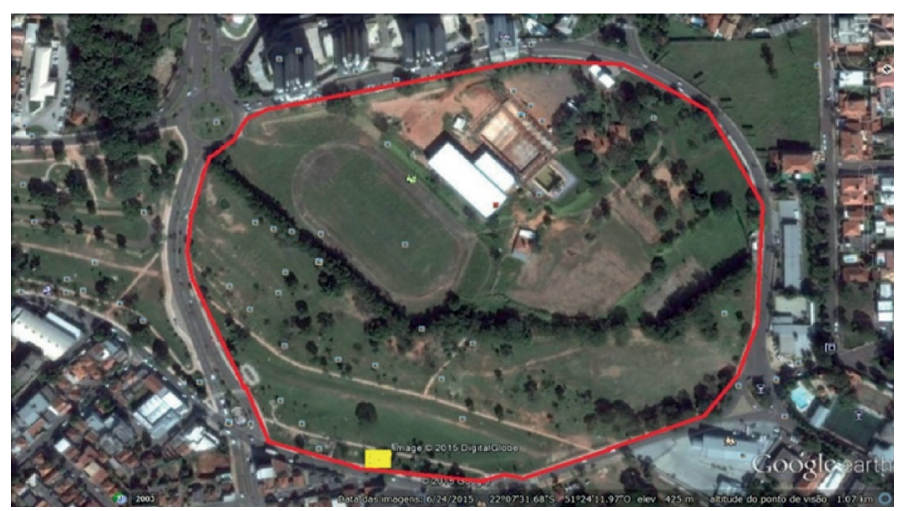

Figure 1. Parque do Povo route. Source: fieldwork (2016)

\section{RESULTS}

A deeper analysis of the initially proposed questions implied an empirical research involving volunteers who performed physical exercise at Parque do Povo, located in Presidente Prudente, SP, Brazil. The hypothesis was that urban green areas provide environmental quality in performing physical exercise. Urban life is often seen as stressful, polluted, and filled with conflicts that can affect the population's well-being. The sample included 36 volunteers ( 17 women and 19 men) who were analyzed in two phases: January 2016 (summer) and July 2016 (winter).

Table 1 shows participants' characteristics in both study phases. These values were collected at rest and before the start of the intervention and are expressed as mean \pm standard deviation. 
Table 1. Characteristics of participants in two study phases: February 2016 and July 2016.

\begin{tabular}{|c|c|c|}
\hline \multicolumn{3}{|c|}{ First phase: February 2016, total respondents = 36 (17 women and 19 men } \\
\hline \multirow[t]{2}{*}{ Variables } & \multicolumn{2}{|c|}{ Mean \pm standard deviation } \\
\hline & Men & Women \\
\hline Age (years) & $27.42 \pm 5.8$ & $23.30 \pm 5.7$ \\
\hline Height $(m)$ & $1.77 \pm 0.0$ & $1.65 \pm 0.0$ \\
\hline Weight (kg) & $82.78 \pm 17.5$ & $64.40 \pm 17.2$ \\
\hline $\mathrm{BMI}\left(\mathrm{kg} / \mathrm{m}^{2}\right)$ & $26.45 \pm 4.8$ & $23.56 \pm 4.6$ \\
\hline Abdominal circumference & $87.63 \pm 14.4$ & $74.38 \pm 14.3$ \\
\hline $\mathrm{SP}(\mathrm{mmHg})$ & $119.79 \pm 8.2$ & $112.35 \pm 6.6$ \\
\hline $\mathrm{DP}(\mathrm{mmHg})$ & $77.89 \pm 17.8$ & $75.88 \pm 7.1$ \\
\hline Heart rate & $86.74 \pm 11.7$ & $79.53 \pm 12.6$ \\
\hline Respiratory rate & $27.58 \pm 3.1$ & $25.12 \pm 2.9$ \\
\hline \multicolumn{3}{|c|}{ Second phase: July 2016 , total respondents $=36$ ( 17 women and 19 men } \\
\hline \multirow[t]{2}{*}{ Variable } & \multicolumn{2}{|c|}{ Mean \pm standard deviation } \\
\hline & Men & Women \\
\hline Age (years) & $27.42 \pm 5.8$ & $23.30 \pm 5.7$ \\
\hline Height (m) & $1.77 \pm 0.0$ & $1.65 \pm 0.0$ \\
\hline Weight (kg) & $82.78 \pm 17.5$ & $64.40 \pm 17.2$ \\
\hline $\mathrm{BMI}\left(\mathrm{kg} / \mathrm{m}^{2}\right)$ & $46.98 \pm 32.7$ & $42.91 \pm 27.2$ \\
\hline Abdominal circumference & $93.18 \pm 13.8$ & $75.53 \pm 11.4$ \\
\hline $\mathrm{SP}(\mathrm{mmHg})$ & $122.94 \pm 11.6$ & $110.00 \pm 8.8$ \\
\hline $\mathrm{DP}(\mathrm{mmHg})$ & $63.53 \pm 31.0$ & $74.37 \pm 6.1$ \\
\hline Heart rate & $80.71 \pm 12.8$ & $77.84 \pm 7.7$ \\
\hline Respiratory rate & $23.23 \pm 3.1$ & $23.10 \pm 1.8$ \\
\hline
\end{tabular}

Source: fieldwork (2016). BMI, body mass index; SP, systolic blood pressure; DP, diastolic blood pressure.

Table 1 shows that the mean age in men was 27 years, 22\% were aged between 18 and 23 years, and $36 \%$ were aged between 24 and 30 years. The mean age in women was 23 years, $27 \%$ were aged between 18 and 23 years, and $11 \%$ were aged between 24 and 30 years.

The mean systolic blood pressure in the first phase (February 2016) was $119.7 \mathrm{mmHg}$ in men and $112.3 \mathrm{mmHg}$ in women, which are considered to be within the normal limits. In the second phase (July 2016), the mean systolic blood pressure was $122.9 \mathrm{mmHg}$ in men, which was higher than that in the first phase and above the standard normal value.

Hypertension is considered when the systolic blood pressure is $\geq 140 \mathrm{mmHg}$ and diastolic blood pressure is $\geq 90 \mathrm{mmHg}$ in individuals not using antihypertensive medication. The normal blood pressure established in the medical setting is $<120 / 80 \mathrm{mmHg} .{ }^{6}$ Thus, in this study, all participants had normal blood pressure. The mean diastolic blood pressure in the first phase (February 2016) was $77.8 \mathrm{mmHg}$ in men and $75.8 \mathrm{mmHg}$ in women, which are considered to be within the normal limits. In the second phase (July 2016), the mean diastolic blood pressure was $63.5 \mathrm{mmHg}$ in men and $74.3 \mathrm{mmHg}$ in women, which were within the normal limits.

A study by Grassi presented data that corroborate with those in our study. The author analyzed normotensive young volunteers and reported decreased systolic and diastolic blood pressures after 10 weeks of physical exercise, in addition to a significant reduction in the sympathetic nervous activity (36\%), which was also observed in our study, as the population was normotensive and healthy.

The heart rate is an indicator of cardiac work represented by the number of times the heart beats per minute. Heart rate reference values may vary with the patient's age. A sedentary adult should present a normal value of 70-80 beats per minute (bpm), while athletes have a heart rate of $50 \mathrm{bpm} .{ }^{27}$

The mean heart rate in the first phase (February 2016) was 86.7 bpm in men and $79.5 \mathrm{bpm}$ in women, which were considered to be within the normal limits. In the second phase (July 2016), the mean heart rate was $80.7 \mathrm{bpm}$ in men and $77.8 \mathrm{bpm}$ in women, which were within the normal limits.

The values reported in this study corroborate with those reported in the study of Teixeira, ${ }^{3}$ who revealed that low-intensity physical exercise lowers the blood pressure due to decreased cardiac output, which can be explained by decreased resting heart rate and decreased cardiac sympathetic tonus resulting from lower sympathetic intensification and greater vagal withdrawal.

In another study, the authors showed that physically and aerobically well-trained or conditioned individuals have lower resting heart rate, which can be explained by greater parasympathetic or lower sympathetic activity.

However, Melanson and Freedson ${ }^{9}$ reported expressive results in autonomic markers, such as heart and respiratory rates, in healthy individuals undergoing aerobic training, suggesting that these gains are not age-dependent. These study results corroborate with those found in the present study as all vital sign indicators were normal.

The respiratory rate is usually measured by observing chest expansion and counting the number of breaths per minute. At rest, a normal adult breathes comfortably at 12-20 times per minute. ${ }^{6}$

In the first phase (February 2016), the mean respiratory rate was 27.5 per minute in men and 25.1 per minute in women, which are considered to be within the normal limits. In the second phase (July 2016), the mean respiratory was 23.2 per minute in men and 23.1 per minute in women, which were within the normal limits. However, there was a decrease in the respiratory rate in both sexes in the second phase.

During an exercise period, the human body undergoes cardiovascular and respiratory adaptations to meet the increased demands from active muscles. As these adaptations are repeated, these muscles undergo modifications that result in improved body performance. Physiological and metabolic processes are triggered to optimize oxygen distribution to active tissues. ${ }^{10}$ All participants presented normal vital signs as they are healthy and regularly perform physical exercise.

Normal abdominal circumferences are related to absolute circumference (>102 cm in men and $>88 \mathrm{~cm}$ in women). However, the relationship between abdominal circumference and body fat differs by age and ethnic group. ${ }^{6}$

In the first phase (February 2016), the mean abdominal circumference was $87.6 \mathrm{~cm}$ in men and $74.3 \mathrm{~cm}$ in women. In the second phase (July 2016), the mean abdominal circumference was $93.1 \mathrm{~cm}$ in men and 75.5 $\mathrm{cm}$ in women, showing that both sexes maintained normal abdominal circumference in both phases.

A study by Cole et al. ${ }^{11}$ in six countries (England, Brazil, Hong Kong, Singapore, the Netherlands, and the USA) has been accepted and recommended for population-based epidemiological studies. The authors developed overweight and obesity cutoff points based on the correlation between body mass indexes (BMIs) $>85$ and $>95$ for age and sex in the pediatric age group, which correspond to the cutoff points for overweight $\left(>25 \mathrm{~kg} / \mathrm{m}^{2}\right)$ and obesity $\left(>30 \mathrm{~kg} / \mathrm{m}^{2}\right)$, respectively, in the adult age group.

BMI does not distinguish different types of adiposity, some of which may be associated with cardiovascular disease. More recent studies on different types of adipose tissue show, for example, that central (apple-shaped, typically male) obesity has a much higher correlation with cardiovascular disease than BMI. ${ }^{6}$ However, in this study, we found no change in the participants' abdominal circumference. 
There was a correlation between BMI and respiratory rate in the first phase as both variables increased, but this correlation was considered weak $(P=0.48)$. There was no correlation between these variables in the second phase $(P=0.08)$.

We found a significant correlation between BMI and systolic blood pressure in the first phase $(P=0.56)$ as both variables increased. In the second phase, there was a significant but weak correlation ( $P=0.35)$.

The IPAQ results for physical activity levels are presented in Figure 2.

There was an increase from 13 to 19 participants classified as "very active" and a decrease from 20 to 11 participants classified as "active" in the second phase. We found that some participants increased the frequency and intensity of exercises from February to July 2016, most of whom were men.

While the participants perform exercise, the researchers explained the importance of physical exercise, training, and healthy diet. When individuals understand the importance of constant exercise practice, they may feel more motivated to maintain or increase physical exercise performance, as shown in this study.

Several studies reiterate the influence of green areas in increasing physical exercise performance. ${ }^{12,13}$ Arana and Xavier ${ }^{12}$ reported that the maintenance of urban green areas has always been justified by their potential to provide environmental quality to the population.

Sawada et al. ${ }^{13}$ and Xavier ${ }^{14}$ reported that Parque do Povo provides a place for physical exercise, in addition to green and multiple-use areas including running tracks and game courts, snack bars, police stations, and even photocopying service centers.

As for the physical activity levels, we used the chi-square test to verify whether different collection phases actually influenced the IPAQ results, which showed that the IPAQ classification was not influenced by the collection period ( $P=0.09$ ). Figure 3 shows an analysis of physical activity level in both phases by sex.

A comparison between both phases showed equal values for both sexes and an expressive number of very active participants. As for phase

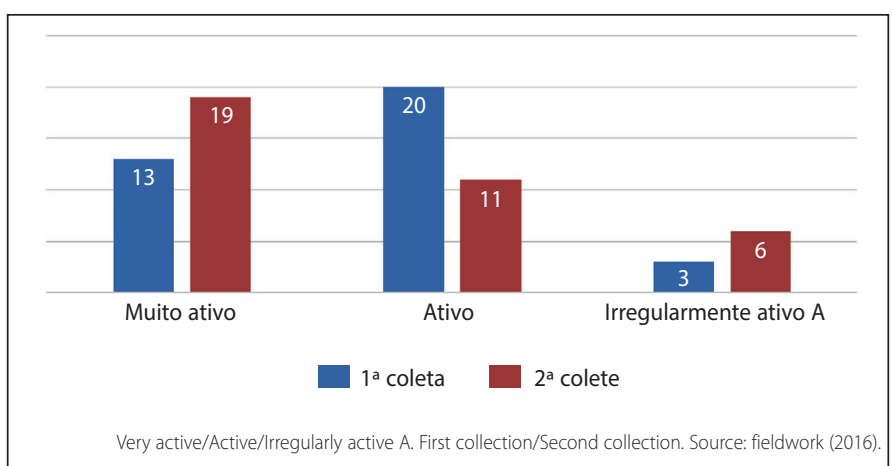

Figure 2. IPAQ results in February and July data collection.

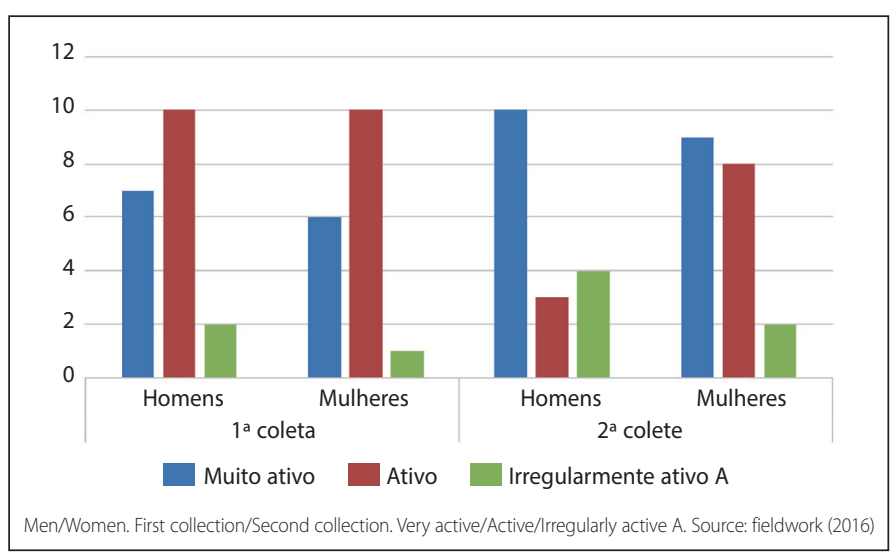

Figure 3. IPAQ classification in February and July data collection by sex. collection, the IPAQ classification was not influenced by sex $(P=0.8$ in the first phase and $P=0.2$ in the second phase).

There were an increased number of very active participants in the second phase. The percentage of very active men was 36\% (7 men) in the first phase and 58\% (10 men) in the second phase. The percentage of very active women was 35\% (6 women) in the first phase and $47 \%$ ( 9 women) in the second phase.

This result corroborates that of other studies as it shows that the highest percentage of participants classified as very active were men. ${ }^{15}$ Some other studies reported higher percentages of very active women, 16,17 not corroborating with the results of this study, in which there was a higher percentage of very active men.

\section{DISCUSSION}

Participants included in this study presented normal vital signs and hemodynamic factors, showing a minor variation during the practice of the proposed exercise, as they were all healthy and physically active adults.

However, the study showed that physical exercise causes a series of physiological responses resulting from autonomic and hemodynamic adaptations that influence the cardiovascular system and work as an important non-medication control element or adjuvant to pharmacological treatment.

The results of the recent study by Arana and Xavier ${ }^{12}$ corroborate with our findings. They showed that the green environment is the main factor that influenced park users to practice physical activity at Parque do Povo.

Some authors reported that parks would probably stimulate physical activity due to motivational factors as individuals would feel happier exercising in a green route with trees than in empty spaces. There is also evidence that having access to these areas contributes to increase physical activity levels. ${ }^{18}$

A study by Xavier ${ }^{14}$ shows that most park users reported not having professional orientation to practice physical activity (67\%), and only 17\% and $16 \%$ followed medical advice or recommendations of a physical education professional, respectively. This shows that a large percentage of the population using Parque do Povo has no health professional orientation. These data reveal the importance of the orientation provided in our study.

Moreover, public health campaigns can encourage people to use green spaces and exercise outdoors more frequently. The health benefits attributed to these environments should be better known in order to make these places more effective for the population. ${ }^{18}$

The city of Presidente Prudente has public spaces for physical exercise practice in areas exposed to vehicle emissions. However, this study shows the importance of exercising in an open air environment, being validated by Cuissi ${ }^{19}$ who reported that closed environments with poor ventilation present a greater health risk due to more difficult pollution dispersion.

\section{CONCLUSION}

The present study showed that participants became more active, possibly due to the motivation provided by a green and well-structured environment. It is important to emphasize that this study also provided individual orientation to its participants, which included health education, motivating them to increase exercise frequency and intensity, a fact that we could observe in the second data collection with an increased number of more active participants. The investigation of interdependence among physical activity, health, and environment provides an essential element for the society, thus allowing us to recommend effective collective health measures to contribute to the population's well-being.

All authors declare no potential conflict of interest related to this article 
AUTHORS' CONTRIBUTIONS: Each author made significant individual contributions to this manuscript. JF (0000-0002-6682-9159)*: participated in the drafting of the project, data collection, data analysis and drafting of the article; ARAA (0000-0001-8995-4449)*: participated in the intellectual concept of the article, in the data analysis and writing of the article; MVPR (0000-0002-3997-369X)*: data analysis and drafting of the article; ADF (0000-0003-0102-1738)*: participated in the data analysis and drafting of the article; ESF (0000-00026612-3981)*: participated in the data analysis and in the review of the article; and GGSR (0000-0002-7763-7742)*: participated in the statistical analysis and review of the article. All authors approved the final version of the manuscript. *ORCID (Open Researcher and Contributor ID).

\section{REFERENCES}

1. Miranda MJ, Baptista TJ. A Poluição do ar na cidade de Goiânia-GO e a prática de exercícios físicos. Educ Fis Rev. 2008 [acesso em 2017 jan 12];2(3):1-11. Disponível em: https://portalrevistas.ucb.br/ index.php/efr/article/view/969/952.

2. Benini SM. Áreas verdes públicas: a construção do conceito e a análise geográfica desses espaços no ambiente urbano. 2009. Dissertação [Mestrado em Geografia]. Faculdade de Ciências e Tecnologia, Universidade Estadual Paulista, Presidente Prudente, SP, 2005.

3. Teixeira JA. Hipertensão arterial sistêmica e atividade física. Rev Socerj. 2000;13:25-30

4. Miot HA. Tamanho da amostra em estudos clínicos e experimentais. J Vasc Bras. 2011;10(4):275-8.

5. Pardini R, Matsudo S, Araújo T, Matsudo V, Andrade E, Braggion G, et al. Validação do questionário internacional de nível de atividade física (IPAQ - versão 6): estudo piloto em adultos jovens brasileiros. Rev Bras Ciênc Mov 2001;9(3):45-51

6. Sociedade Brasileira de Cardiologia; Sociedade Brasileira de Hipertensão; Sociedade Brasileira de Nefrologia. VI Diretrizes Brasileiras de Hipertensão. Arq Bras Cardiol.2010;95(1 Suppl 1):1-51

7. Grassi G, Seravalle G, Calhoun DA, Mancia G. Physical training and baroreceptor control of sympathetic nerve activity in humans. Hypertension. 1994;23(3):294-301.

8. Aubert AE, Beckers F, Ramaekers D. Short-term heart rate variability in young athletes. J Cardiol. 2001;37 (Suppl 1):85-8.

9. Melanson EL, Freedson PS. The effect of endurance training on resting heart rate variability in sedentary adult males. Eur J Appl Physiol. 2001;85(5):442-9.

10.Thompson WR, Gordon NF, Pescatello LS; American College of Sports Medicine. ACSM's Guidelines for Exercise Testing and Prescription. 8th. ed. Philadelphia: Lippincott Williams \&Wilkins, 2010
11. Colet TJ, Bellizzi MC, Flegal KM, Dietz WH. Establishing a standard definition for child overweight and obesity worldwide: international survey. BMJ. 2000;320(7244):1240-3.

12. Arana AR, Xavier FB. Qualidade ambiental e promoção de saúde: um estudo sobre o Parque do Povo de Presidente Prudente-SP. Rev Depart Geogr. 2016;32:1-14.

13. awada FT, Trajano GS, Nunes LF, Malavazzi MA, Freitas R, Silva EW. Análise espaço-temporal do parque do povo de Presidente Prudente a partir de fotos aéreas e imagem orbital. 2007. Trabalho de Conclusão de Curso [Graduação em Engenharia Cartográfica]. Faculdade de Ciências e Tecnologia, Universidade Estadual Paulista, Presidente Prudente, 2007.

14. Xavier FB. Qualidade Urbana Ambiental e prática de atividades físicas: um estudo sobre o Parque do Povo de Presidente Prudente. 2016. 112 f. Dissertação [Mestrado em Meio Ambiente e Desenvolvimento Regional]. Universidade do Oeste Paulista, Presidente Prudente, SP. 2016.

15. Matsudo V, Andrade E, Matsudo S, Araújo T, Andrade D, Oliveira L, et al. Moderate, vigorous, and walking messages adopting in a physical activity intervention program as related to chronological age. Med Sci Sports Exer. 2001;33(Suppl 5):S50.

16. Gonela JT, Santos MA, Castro V, Damasceno MM, Zanetti ML. Nível de atividade física e gasto calórico em atividades de lazer de pacientes com diabetes mellitus Rev Bras Educ Fis Esporte. 2016;30(3):575-82.

17. Bauman A, Bull F, Chey T, Craig CL, Ainsworth BE, Sallis JF. The international prevalence study on physical activity: results from 20 countries. Int J Behav Nutr Phys Act., 2009;6:21.

18. Szeremeta B, Zannin PH. A importância dos parques urbanos e áreas verdes na promoção da qualidade de vida em cidades. Rev Ra'ega. 2013; 29:177-93.

19. Cuissi RC. Efeitos da poluição atmosférica no sistema respiratório de indivíduos praticantes de exercício físico aeróbio em ambiente aberto e fechado. 2014. Dissertação [Mestrado em Fisioterapia]. Universidade Estadual Paulista, Faculdade de Ciências e Tecnologia, Presidente Prudente-SP. 2014. 